Conference Presentation

\title{
Antitumoral activity of homeopathic and anthroposophic Viscum album's preparations: an in vitro assay
}

\author{
Joao Vitor da Costa Batista1, Michelle Nonato de Oliveira Melo', Adriana Passos Oliveira ${ }^{1}$, \\ Ezequiel Paulo Viriato ${ }^{2,3}$, Stephan Baumgartner ${ }^{4,5}$, Carla Holandino ${ }^{1}$ \\ ${ }^{1}$ Laboratório Multidisciplinar de Ciências Farmacêuticas, Faculdade de Farmácia, Universidade Federal do Rio \\ de Janeiro, Rio de Janeiro - RJ, Brazil. cholandino@gmail.com \\ 2Faculdade Oswaldo Cruz, São Paulo - SP, Brazil. \\ ${ }^{3}$ Laboratório Homeopático Almeida Prado, São Paulo - SP, Brazil. \\ ${ }^{4}$ Society for Cancer Research, Hiscia Institute, Arlesheim, Switzerland. \\ ${ }^{5}$ Institute of Integrative Medicine, University of Witten-Herdecke, Herdecke, Germany.
}

\begin{abstract}
Background: Viscum album (mistletoe) has been used for a variety of purposes and is widely used as an alternative treatment for cancer and other diseases. Preparations of fermented extracts from Viscum album (VA), a plant from the Loranthaceae family, have been used, mainly in European countries, with promising results as adjuvant therapies, especially in Anthroposophic Medicine.1,2,3. In vitro studies have demonstrated that various types of VA may have cytotoxic activity in carcinoma cells, being able to activate the apoptotic cascade or leading cells to necrosis. It is possible to prepare VA extracts using different procedures and solvents. The homeopathic preparations involve the use of ethanol as solvent ${ }^{4}$, while the antroposophic preparations are obtained in aqueous solvent ${ }^{5}$.
\end{abstract}

Aims: The present study aimed to verify the cytotoxic effects of homeopathic and anthroposophic Viscum album preparations in human leukaemic K562 cell line.

Methodology: The cytotoxic effects of anthroposophic (ISCADOR A - IA; ISCADOR P - IP; ISCADOR M - IM; ISCADOR U - IU; ISCADOR Qu - IQu) and homeopathic Viscum album extracts (VA) were evaluated in K562 cells. For this, ten independent experiments of Trypan blue assay and five independent MTT assay were carried out. ${ }^{6}$ Additionally, cell morphology was analysed by phase inverted contrast microscopy coupled to digital camera (Optika XDS-3). ${ }^{7}$ The results were expressed as mean $\pm \mathrm{SD}$, and statistical comparisons were performed by one-way ANOVA.

Results: All samples tested were able to interfere with viability and mitochondrial activity, with important morphological damage, when compared to respective controls. Considering the ISCADOR samples all of them presented similar cytotoxic activity, with lower activity attribute to IP (around $25 \%$ of viable cells) in comparison to $90 \%$ of non-viable cells induced by other samples. The homeopathic preparation originated the best results compared to anthroposophic samples. Morphological analyses supported the MTT and trypan blue assays' results.

OPEN ACCESS

Cite as: Batista JVC, Melo MNO, Oliveira AP, Viriato EP, Baumgartner S, Holandino C. Antitumoral activity of homeopathic and anthroposophic Viscum album's preparations: an in vitro assay. Proceedings of the XXIX GIRI Meeting; 2015 June 3 5; Verona (Italy). Int J High Dilution Res. 2015; 14(2): 53-54 
Proceedings of the XXIX GIRI Meeting; 2015 June 3 - 5; Verona (Italy).

International Journal of High Dilution Research 2015; 14(2): 53-54.

Available online at www.highdilution.org

Conclusion: The anticancer activity tested in K562 indicate that all Viscum album samples have anticancer activity, in a dose dependent manner. Further tests need to be done in order to contribute for the understanding of the Viscum album antitumoral mechanisms, as well as about differences between homeopathic and antroposophic procedures.

\section{References:}

1. Troger W, Galun D, Reif M, Schumann A, Stankovic N, Milicevic M. Viscum album [L.] extract therapy in patients with locally advanced or metastatic pancreatic cancer: A randomised clinical trial on overall survival. European Journal of Cancer 2013;49(18):3788-97.

2. Bar-Sela G. White-Berry Mistletoe (Viscum album L.) as complementary treatment in cancer: Does it help? European Journal of Integrative Medicine 2011;3(2):55-62.

3. Sung NY, Byun EB, Song DS, Jin YB, Kim JK, Park JH, Song BS, Jung PM, Byun MW, Lee JW, Park SH, Kim JH. Effect of gamma irradiation on mistletoe (Viscum album) lectin-mediated toxicity and immunomodulatory activity. Federation of European Biochemical Societies (FEBS) Open Bio 2013;3:106-11.

4. French Homeopathy Pharmacopeia, Preparations-homeopathiques, Mistletoe from the appletree Viscum album 2010.

5. Magano DA. Viscum album: pharmaceutical preparations for use in anthroposophic therapy. Arte Médica Ampliada 2012;32(2):72-79.

6. de Campos VE, Teixeira CA, da Veiga VF, Ricci E Jr, Holandino C. L-Tyrosine-loaded Nanoparticles Increase the Antitumoral Activity of Direct Electric Current in a Metastatic Melanoma Cell Model. International Journal of Nanomedicine 2010;5:961-71.

7. Teixeira CAA, Veiga VF, Morales MM, Holandino C. Molecular Aspects Associated with Tumor Electrotherapy: a Study Using an In Vitro Lung Cancer Cell Model In: XXI International Symposium on Bioelectrochemistry and Bioenergetics of the Bioelectrochemical Society (BES), 2011, Cracow.

\section{Supporting Agencies: FAPERJ}

Keywords: Viscum album, cancer, homeopathy, anthroposophic medicine

(C) International Journal of High Dilution Research. Not for commercial purposes.

\section{OPEN ACCESS}

Cite as: Batista JVC, Melo MNO, Oliveira AP, Viriato EP, Baumgartner S, Holandino C. Antitumoral activity of homeopathic and anthroposophic Viscum album's preparations: an in vitro assay. Proceedings of the XXIX GIRI Meeting; 2015 June 3 5; Verona (Italy). Int J High Dilution Res. 2015; 14(2): 53-54 